\title{
Accretion Product Formation from Self- and Cross-Reactions of RO2 Radicals in the Atmosphere
}

\section{Berndt, Torsten}

2018-03-26

Berndt , T , Scholz , W, Mentler , B , Fischer , L, Herrmann , H, Kulmala , M \& Hansel , A 2018 , ' Accretion Product Formation from Self- and Cross-Reactions of RO2 Radicals in the Atmosphere ' , Angewandte Chemie (International Edition) , vol. 57 , no. 14 , pp. 3820-3824 . https://doi.org/10.1002

http://hdl.handle.net/10138/325745

https://doi.org/10.1002/anie.201710989

unspecified

acceptedVersion

Downloaded from Helda, University of Helsinki institutional repository.

This is an electronic reprint of the original article.

This reprint may differ from the original in pagination and typographic detail.

Please cite the original version. 


\section{Accretion product formation from self- and cross-reactions of $\mathrm{RO}_{2}$ radicals in the atmosphere}

Torsten Berndt ${ }^{[\mathrm{a}]^{*}}$, Wiebke Scholz ${ }^{[\mathrm{b}]}$, Bernhard Mentler ${ }^{[\mathrm{b}]}$, Lukas Fischer ${ }^{[\mathrm{b}]}$, Hartmut Herrmann ${ }^{[\mathrm{a}]}$, Markku Kulmala ${ }^{[\mathrm{c}]}$, and Armin Hansel ${ }^{[\mathrm{b}, \mathrm{c}]}$

[a] Leibniz Institute for Tropospheric Research (TROPOS), Atmospheric Chemistry Dept. (ACD), 04318 Leipzig, Germany.

${ }^{[b]}$ Institute for Ion Physics and Applied Physics, University of Innsbruck, 6020 Innsbruck, Austria.

${ }^{[c]}$ Department of Physics, University of Helsinki, Helsinki 00014, Finland.

*corresponding author 


\begin{abstract}
Hydrocarbons are emitted into Earth's atmosphere in very large quantities by human and biogenic activities. Their atmospheric oxidation processes almost exclusively form $\mathrm{RO}_{2}$ radicals as reactive intermediates whose atmospheric fate is not fully discovered yet. Here we show that gas-phase reactions of two $\mathrm{RO}_{2}$ radicals produce accretion products composed of the carbon backbone of both reactants. $\mathrm{RO}_{2}$ radicals bearing functional groups show fast accretion product formation rates competing with those of the corresponding reactions with $\mathrm{NO}$ and $\mathrm{HO}_{2}$. This pathway, not considered yet in the modelling of atmospheric processes, can be important, or even dominant for the fate of $\mathrm{RO}_{2}$ radicals in all areas of the atmosphere. Moreover, the formed accretion products can be featured by remarkably low vapour pressure characterizing them as effective source for secondary organic aerosol.
\end{abstract}


The global emission rate of non-methane hydrocarbons from vegetation and human activities into the atmosphere is estimated to be about $1.3 \times 10^{9}$ metric tons of carbon per year. ${ }^{[1]}$ Their gas-phase degradation process is mainly initiated by the reaction with hydroxyl $(\mathrm{OH})$ or nitrate $\left(\mathrm{NO}_{3}\right)$ radicals, chlorine atoms or ozone $\left(\mathrm{O}_{3}\right) .{ }^{[2]}$ After initial attack of the oxidant, $\mathrm{RO}_{2}$ radicals are almost exclusively formed as intermediates, which rapidly react further with $\mathrm{NO}, \mathrm{HO}_{2}$ or other $\mathrm{RO}_{2}$ radicals or via $\mathrm{RO}_{2}$ radical self-reaction. More recently, also effective $\mathrm{RO}_{2}$ radical isomerization steps have been discovered, i.e. the $\mathrm{RO}_{2}$ autoxidation ${ }^{[3]}$ and the endo-cyclization of unsaturated $\mathrm{RO}_{2}$ radicals ${ }^{[4]}$ finally leading to higher functionalization of the $\mathrm{RO}_{2}$ radicals.

It is currently accepted that the main products of the self- and cross-reaction of $\mathrm{RO}_{2}$ radicals are either the corresponding oxyl radicals (RO), pathway (1a), or an alcohol (ROH) in conjunction with a carbonyl $\left(\mathrm{R}^{\prime}(-\mathrm{H},=\mathrm{O})\right)$, pathway $(1 \mathrm{~b}){ }^{[5]}$

$$
\begin{array}{rll}
\mathrm{RO}_{2}+\mathrm{R}^{\prime} \mathrm{O}_{2} & \rightarrow & \mathrm{RO}+\mathrm{R}^{\prime} \mathrm{O}+\mathrm{O}_{2} \\
& \rightarrow & \mathrm{ROH}+\mathrm{R}^{\prime}(-\mathrm{H},=\mathrm{O})+\mathrm{O}_{2}
\end{array}
$$

As a result of earlier studies, the formation of dialkyl peroxides has been discussed additionally, pathway (1c). Stated peroxide yields from the self-reaction of the simplest $\mathrm{RO}_{2}$ radicals, $\mathrm{RO}_{2}=\mathrm{R}^{\prime} \mathrm{O}_{2}=$ $\mathrm{CH}_{3} \mathrm{O}_{2}, \mathrm{C}_{2} \mathrm{H}_{5} \mathrm{O}_{2}$ or $\mathrm{CH}_{3} \mathrm{C}(\mathrm{O}) \mathrm{O}_{2}$, were reported to be small. ${ }^{[6]}$

$$
\mathrm{RO}_{2}+\mathrm{R}^{\prime} \mathrm{O}_{2} \quad \rightarrow \quad \mathrm{ROOR}^{\prime}+\mathrm{O}_{2}
$$

The relevance of pathway (1c) has not been investigated yet for $\mathrm{RO}_{2}$ radicals other than for the small model $\mathrm{RO}_{2}$ radicals and is currently not considered in atmospheric modelling. ${ }^{[7]}$ However, recent experimental findings, especially from gas-phase ozonolysis of cyclohexene ${ }^{[8]}$ and terpenes ${ }^{[3 b, 3 c, 9]}$, point to accretion product formation that could be at least partly explained by a process according to pathway (1c). It should be noted that $\mathrm{ROOR}^{\prime}$ formation is also discussed for $\mathrm{RO}_{2}$ radical reactions occurring in the liquid phase. ${ }^{[10]}$

Here we report on an experimental study focusing on the formation of accretion products with the chemical composition ROOR' that can be explained via pathway (1c). The investigations have been performed in a free-jet flow system under atmospheric conditions in the absence of noticeable wall effects ${ }^{[3 \mathrm{~d}, 8 \mathrm{~b}]} \cdot \mathrm{RO}_{2}$ radicals and accretion products from different reaction systems were probed simultaneously by means of latest mass spectrometric techniques, which were recently described ${ }^{[3 \mathrm{~d}, 11]}$ or are applied here for the first time. A detailed description of the experimental approach is given in Supplementary Information.

The findings of this study demonstrate the general validity of accretion product formation via pathway (1c) or related pathways for all possible combinations of $\mathrm{RO}_{2}$ radicals in a particular reaction system. It is to be noted that, at the present stage, we cannot prove the peroxide structure of ROOR', we merely show the formation of products with an exact mass that is in accordance with the chemical composition ROOR'.

First, product formation from the $\mathrm{OH}$ radical initiated oxidation of 1,3,5-trimethylbenzene has been investigated using ozonolysis of tetramethylethylene (TME) as $\mathrm{OH}$ radical source. 1,3,5trimethylbenzene represents an example of aromatic compounds, which are important emissions in urban areas ${ }^{[12]}$ Measured concentrations of the main $\mathrm{RO}_{2}$ radicals, i.e. $\mathrm{CH}_{3} \mathrm{C}(\mathrm{O}) \mathrm{CH}_{2} \mathrm{O}_{2}$ from TME ozonolysis $^{[13]}$ and $\mathrm{HO}-\mathrm{C}_{9} \mathrm{H}_{12}\left(\mathrm{O}_{2}\right)_{\mathrm{x}} \mathrm{O}_{2}$ with $\mathrm{x}=1-3$ from the aromatic ${ }^{[14]}$, increased almost linearly with rising ozone and subsequently rising $\mathrm{OH}$ radical concentrations (Figure 1A). For these reaction conditions, the $\mathrm{RO}_{2}$ formation pathways basically governed the appearing $\mathrm{RO}_{2}$ radical concentrations and loss processes, other than unimolecular pathways, were less important. The good agreement of results of different detection methods between themselves as well as between measured and calculated $\mathrm{CH}_{3} \mathrm{C}(\mathrm{O}) \mathrm{CH}_{2} \mathrm{O}_{2}$ concentrations indicates the accuracy of the measurements. The $\mathrm{HO}-\mathrm{C}_{9} \mathrm{H}_{12}\left(\mathrm{O}_{2}\right)_{\mathrm{x}} \mathrm{O}_{2}$ radical with $\mathrm{x}=1$, initially formed from the $\mathrm{OH}+1,3,5$-trimethylbenzene reaction, is a bicyclic 
species with an endo-peroxide group beside the peroxy radical moiety. ${ }^{[14 a]}$ The corresponding $\mathrm{RO}_{2}$ radicals with $\mathrm{x}=2$ and 3 are most likely formed via repetitive intra-molecular $\mathrm{H}$-shift with subsequent $\mathrm{O}_{2}$ addition leading to one and two OOH groups in the molecule, respectively. ${ }^{[14 \mathrm{~b}]}$
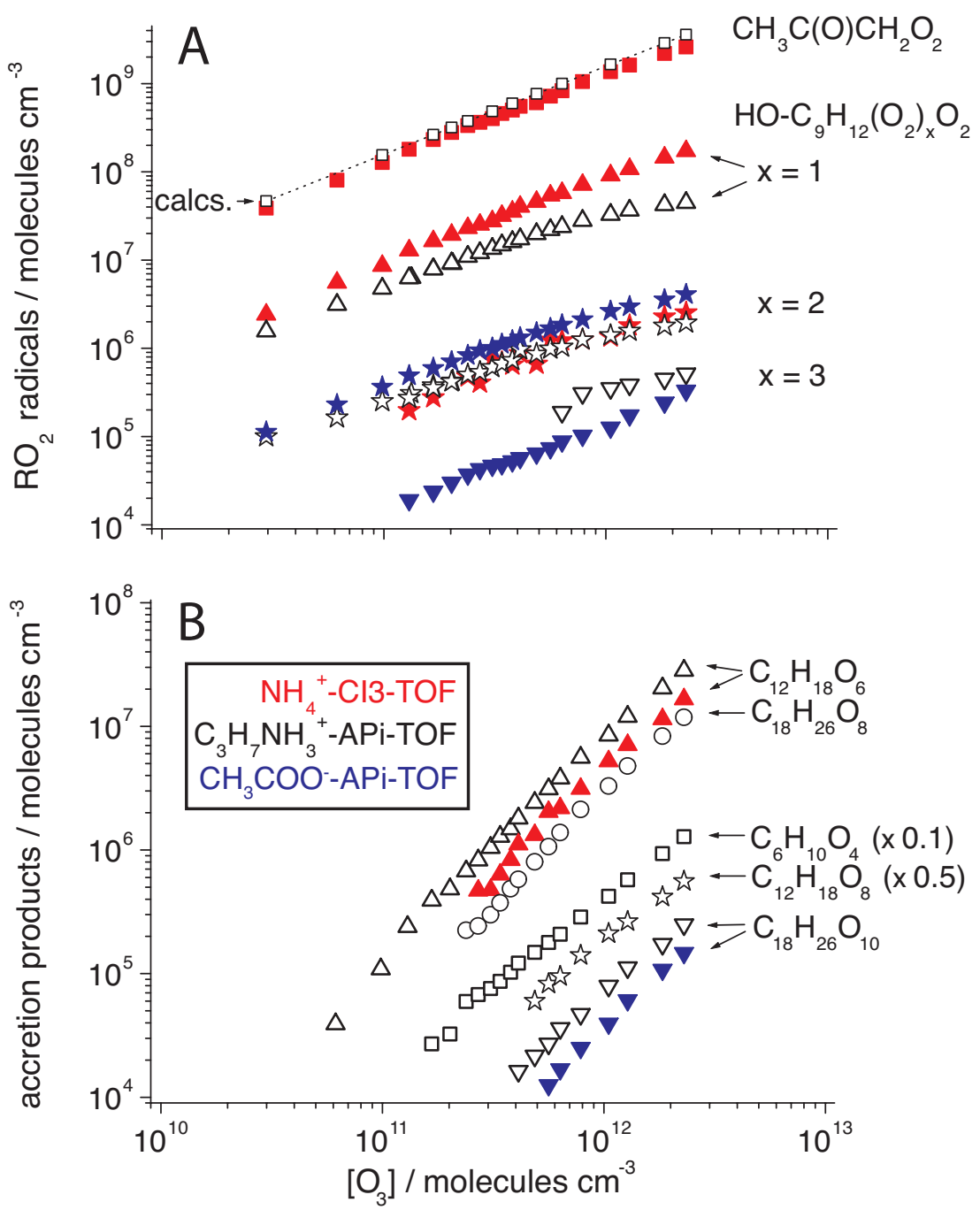

Figure 1. $\mathrm{RO}_{2}$ radicals $\mathbf{A}$ and accretion products $\mathbf{B}$ from the reaction $\mathrm{OH}+1,3,5$-trimethylbenzene using $\mathrm{OH}$ radical formation via ozonolysis of TME (tetramethylethylene). Symbol coding of detection methods: red full: $\mathrm{NH}_{4}{ }^{+}$-CI3-TOF; black open: $\mathrm{C}_{3} \mathrm{H}_{7} \mathrm{NH}_{3}{ }^{+}$-APi-TOF; blue full: $\mathrm{CH}_{3} \mathrm{COO}^{-}$-APi-TOF. Reactant concentrations: $[\mathrm{TME}]=2.0 \times 10^{11}$ and $[1,3,5$-trimethylbenzene $]=4.06 \times 10^{12}$ molecules $\mathrm{cm}^{-3}$. Reaction time was $7.9 \mathrm{~s}$.

Besides the $\mathrm{RO}_{2}$ radicals, also the signals of the accretion products according to pathway (1c) from self- and cross-reactions of the $\mathrm{RO}_{2}$ radicals in the system were detected. Strongest signals appeared for the products $\mathrm{C}_{12} \mathrm{H}_{18} \mathrm{O}_{6}, \mathrm{C}_{18} \mathrm{H}_{26} \mathrm{O}_{8}$ and $\mathrm{C}_{6} \mathrm{H}_{10} \mathrm{O}_{4}$ formed from the possible combinations of the two most abundant $\mathrm{RO}_{2}$ radicals, i.e. from $\mathrm{CH}_{3} \mathrm{C}(\mathrm{O}) \mathrm{CH}_{2} \mathrm{O}_{2}$ and $\mathrm{HO}-\mathrm{C}_{9} \mathrm{H}_{12}\left(\mathrm{O}_{2}\right) \mathrm{O}_{2}$ (Figure 1B and Figure $\mathrm{S} 3$ ). Additional experiments confirmed that unwanted processes did not influence the product formation during the ionization in the mass spectrometer, see Supplementary Information. Proposed pathways leading to the main accretion products are illustrated in Scheme 1. 


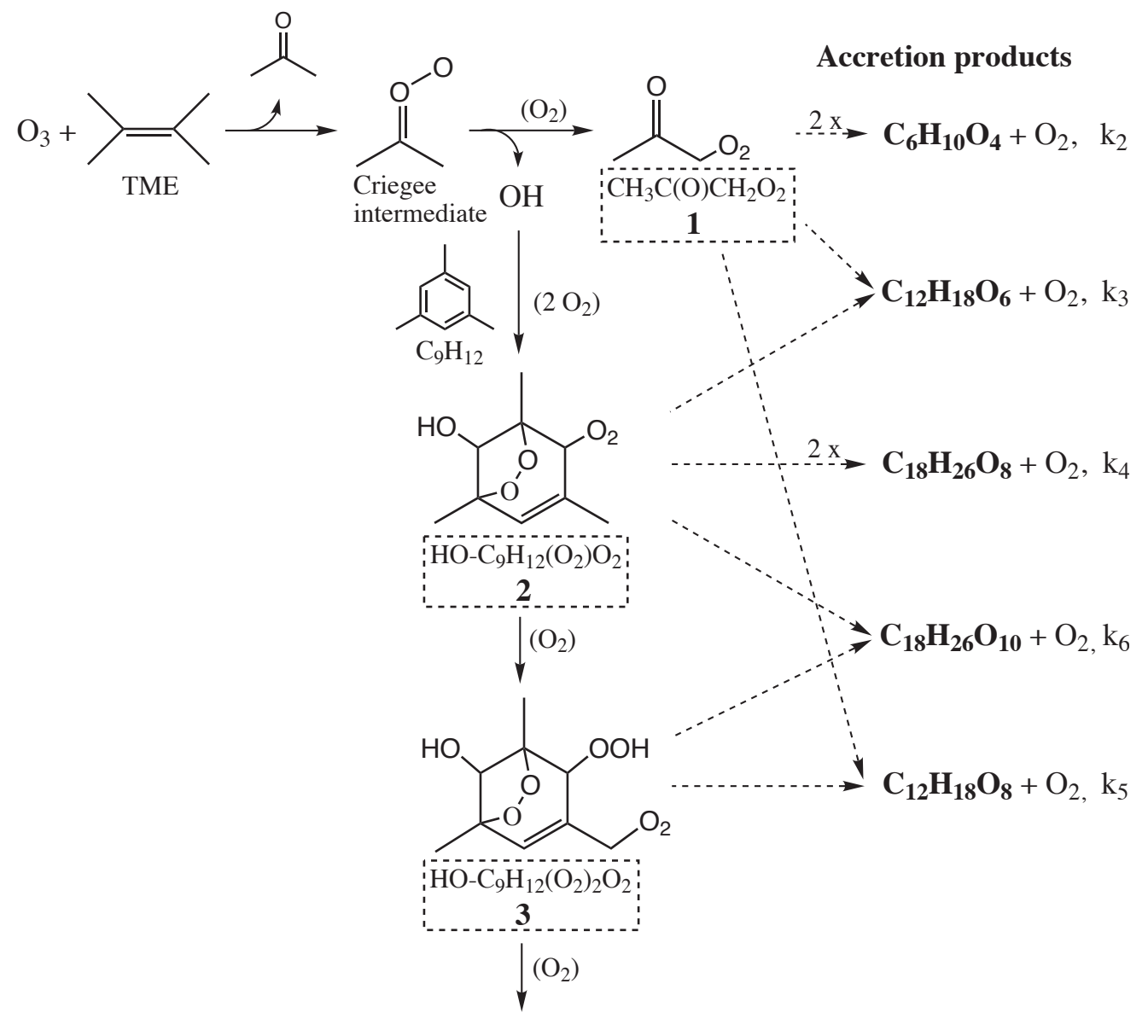

Scheme 1. Proposed pathways for the formation of accretion products from the reaction of OH radicals with 1,3,5-trimethylbenzene $\left(\mathrm{C}_{9} \mathrm{H}_{12}\right)$ using $\mathrm{OH}$ radical formation via TME ozonolysis. The rate coefficients $\mathrm{k}_{2}-\mathrm{k}_{6}$ stand for the respective $\mathrm{RO}_{2}$ self- or cross-reactions. Structures of $\mathbf{2}$ and $\mathbf{3}$ are adopted from ref. 14.

The steeper increase of accretion product concentrations compared with that of $\mathrm{RO}_{2}$ radicals is consistent with a $2^{\text {nd }}$ order kinetics for products of pathway (1c) (Figure 1). The expected linear behaviour, [accretion product] vs. $\left[\mathrm{RO}_{2}\right] \times\left[\mathrm{R}^{\prime} \mathrm{O}_{2}\right]$, was well fulfilled (Figure 2). Thus, the rate coefficients $\mathrm{k}_{2}-\mathrm{k}_{6}$ could be estimated based on the respective $\mathrm{RO}_{2}$ and accretion product measurements as summarized in Table 1 . The resulting uncertainty of the rate coefficients is assumed to be not higher than a factor of $2-3$, see Supplementary Information. 


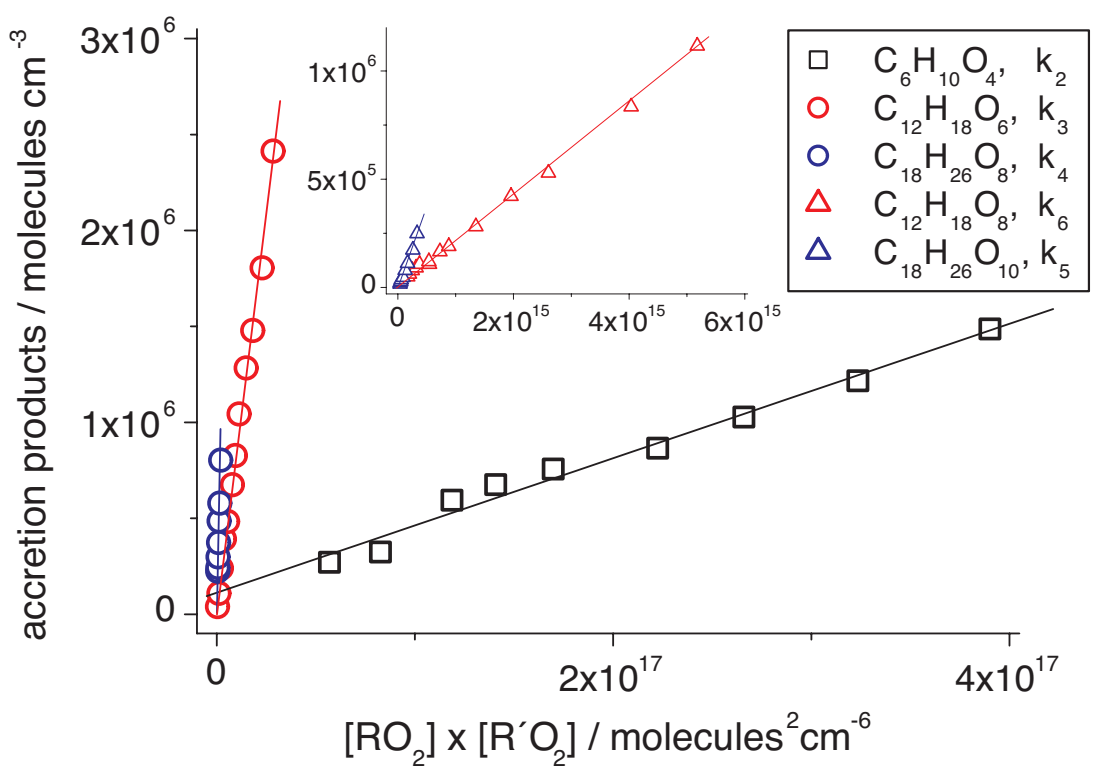

Figure 2. Kinetic analysis of accretion product formation according to pathway (1c), e.g. $\mathrm{RO}_{2}=\mathrm{R}^{\prime} \mathrm{O}_{2}=\mathbf{1}$ for $\mathrm{C}_{6} \mathrm{H}_{10} \mathrm{O}_{4}$, etc. Data were taken from the measurement series as depicted in Figure 1, $\mathrm{RO}_{2}$ radicals from $\mathrm{NH}_{4}{ }^{+}-$ CI3-TOF and accretion products from $\mathrm{C}_{3} \mathrm{H}_{7} \mathrm{NH}_{3}{ }^{+}$-APi-TOF measurements. For $\mathrm{C}_{6} \mathrm{H}_{10} \mathrm{O}_{4}, \mathrm{C}_{12} \mathrm{H}_{18} \mathrm{O}_{6}$ and $\mathrm{C}_{18} \mathrm{H}_{26} \mathrm{O}_{8}$, only results for $\mathrm{O}_{3}$ concentrations smaller than $5 \times 10^{11}$ molecules $\mathrm{cm}^{-3}$ are considered.

Table 1. Rate coefficients of accretion product formation via pathway (1c) from the reaction $\mathrm{OH}+$ 1,3,5-trimethylbenzene using $\mathrm{OH}$ formation via TME ozonolysis that also forms $\mathrm{CH}_{3} \mathrm{C}(\mathrm{O}) \mathrm{CH}_{2} \mathrm{O}_{2}$. The uncertainty of the k-values is assumed to be not higher than a factor of $2-3$.

\begin{tabular}{|c|c|c|c|}
\hline & \multicolumn{3}{|c|}{$\begin{array}{l}\mathbf{R O}_{2}+\mathbf{R}^{\prime} \mathbf{O}_{2} \rightarrow \text { ROOR' }^{\prime}+\mathbf{O}_{2} \\
\text { Rate coefficient }\left(\mathrm{cm}^{3} \text { molecule }\right. \\
\mathrm{T}=295 \pm 2 \mathrm{~K}\end{array}$} \\
\hline & $\begin{array}{c}\mathbf{R}^{\prime} \mathbf{O}_{2}: \\
\mathrm{CH}_{3} \mathrm{C}(\mathrm{O}) \mathrm{CH}_{2} \mathrm{O}_{2} \\
\mathbf{1} \\
\end{array}$ & $\underset{\mathbf{2}}{\mathrm{HO}-\mathrm{C}_{9} \mathrm{H}_{12}\left(\mathrm{O}_{2}\right) \mathrm{O}_{2}}$ & $\begin{array}{c}\mathrm{HO}-\mathrm{C}_{9} \mathrm{H}_{12}\left(\mathrm{O}_{2}\right)_{2} \mathrm{O}_{2} \\
\mathbf{3} \\
\end{array}$ \\
\hline $\begin{array}{c}\mathbf{R O}_{2}: \\
\mathrm{CH}_{3} \mathrm{C}(\mathrm{O}) \mathrm{CH}_{2} \mathrm{O}_{2} \\
\mathbf{1}\end{array}$ & $\begin{array}{c}\left(\mathrm{k}_{2}\right) \\
1.3 \times 10^{-12}\end{array}$ & - & - \\
\hline $\begin{array}{c}\mathrm{HO}-\mathrm{C}_{9} \mathrm{H}_{12}\left(\mathrm{O}_{2}\right) \mathrm{O}_{2} \\
\mathbf{2}\end{array}$ & $\begin{array}{c}\left(\mathrm{k}_{3}\right) \\
3.2 \times 10^{-11} \\
(3.7-5.5) \times 10^{-11 \S}\end{array}$ & $\begin{array}{c}\left(\mathrm{k}_{4}\right) \\
1.4 \times 10^{-10} \\
(1.7-2.5) \times 10^{-10 \S} \\
1.7 \times 10^{-10 \Omega} \\
\end{array}$ & - \\
\hline $\begin{array}{c}\mathrm{HO}-\mathrm{C}_{9} \mathrm{H}_{12}\left(\mathrm{O}_{2}\right)_{2} \mathrm{O}_{2} \\
\mathbf{3}\end{array}$ & $\begin{array}{c}\left(\mathrm{k}_{6}\right) \\
8.0 \times 10^{-11}\end{array}$ & $\begin{array}{c}\left(\mathrm{k}_{5}\right) \\
2.6 \times 10^{-10}\end{array}$ & n.d. \\
\hline
\end{tabular}

$\S$ from $\mathrm{NO}$ experiments assuming $\mathrm{k}\left(\mathrm{NO}+\mathrm{RO}_{2}\right)=10^{-11} \mathrm{~cm}^{3}$ molecule ${ }^{-1} \mathrm{~s}^{-1}$, see text

$\Omega$ from experiments using isopropyl nitrite photolysis as $\mathrm{OH}$ radical source

n.d.: not determined

Accretion product formation accounts for about $16 \%$ of the overall self-reaction of $1, \mathrm{k}_{1 \mathrm{c}} / \mathrm{k}_{1} \sim 0.16$ $\left(\mathrm{k}_{1}=\mathrm{k}_{1 \mathrm{a}}+\mathrm{k}_{1 \mathrm{~b}}+\mathrm{k}_{1 \mathrm{c}}\right)$, based on the obtained rate coefficient $\mathrm{k}_{1 \mathrm{c}}=\mathrm{k}_{2}$ and literature data for the overall rate coefficient $\mathrm{k}_{1}{ }^{[15]}$. An evaluation of the fraction of accretion products from other $\mathrm{RO}_{2}$ self- and cross-reactions is impossible due to the lack of the corresponding overall rate coefficients $\mathrm{k}_{1}$. 
We tested for the influence of $\mathrm{NO}$ on the accretion product formation and estimated $\mathrm{k}_{3}$ and $\mathrm{k}_{4}$ using another independent way (Figure 3). $\mathrm{RO}_{2}$ radical concentrations in the system decreased according to their reactions with NO. The relatively small decrease of $\mathbf{2}$ compared with that of $\mathbf{1}$ is caused by the slightly enhanced formation of $\mathrm{OH}$-derived $\mathrm{RO}_{2}$ radicals with rising $\mathrm{NO}$ due to additional $\mathrm{OH}$ radical production via $\mathrm{HO}_{2}+\mathrm{NO} \rightarrow \mathrm{OH}+\mathrm{NO}_{2}$, see also Figure $\mathrm{S} 4$ for the other $\mathrm{RO}_{2}$ radicals. The concentration of accretion products, e.g. $\mathrm{C}_{18} \mathrm{H}_{26} \mathrm{O}_{8}$ from the self-reaction of 2 and $\mathrm{C}_{12} \mathrm{H}_{18} \mathrm{O}_{6}$ from the cross-reaction of $\mathbf{1}$ with $\mathbf{2}$, followed the decreasing concentrations of their $\mathrm{RO}_{2}$ radical precursors. $\mathrm{HO}-$ $\mathrm{C}_{9} \mathrm{H}_{12}\left(\mathrm{O}_{2}\right) \mathrm{ONO}_{2}$ formation via $\mathrm{NO}+\mathrm{RO}_{2} \rightarrow \mathrm{RONO}_{2}, \mathrm{RO}_{2}=\mathbf{2}$, displays the importance of the $\mathrm{NO}+$ $\mathrm{RO}_{2}$ reaction for rising NO levels. Taking into account a $\mathrm{RONO}_{2}$ yield of $0.2-0.3^{[16]}$, kinetic analysis revealed that the rate coefficient $\mathrm{k}_{4}$ of $\mathrm{C}_{18} \mathrm{H}_{26} \mathrm{O}_{8}$ formation from the self-reaction of $\mathbf{2}$ is by a factor of 17-25 higher than that of the reaction of $\mathrm{NO}$ with 2 (Figure S5). Assuming $\mathrm{k}\left(\mathrm{NO}+\mathrm{RO}_{2}\right)=10^{-11} \mathrm{~cm}^{3}$ molecule $\mathrm{s}^{-1}{ }^{-15]}, \mathrm{k}_{4}=(1.7-2.5) \times 10^{-10} \mathrm{~cm}^{3}$ molecule ${ }^{-1} \mathrm{~s}^{-1}$ follows in good agreement with the value determined from the NO-free measurements. Analogous analysis of $\mathrm{C}_{12} \mathrm{H}_{18} \mathrm{O}_{6}$ formation results in $\mathrm{k}_{3}=$ $(3.7-5.5) \times 10^{-11} \mathrm{~cm}^{3}$ molecule $\mathrm{s}^{-1}$ again in good agreement with the value from the NO-free experiments (Table 1 and Figure S6). These experiments confirm the high values of $k_{3}$ and $k_{4}$ and justify the stated uncertainty of the k-values by a factor of $2-3$.

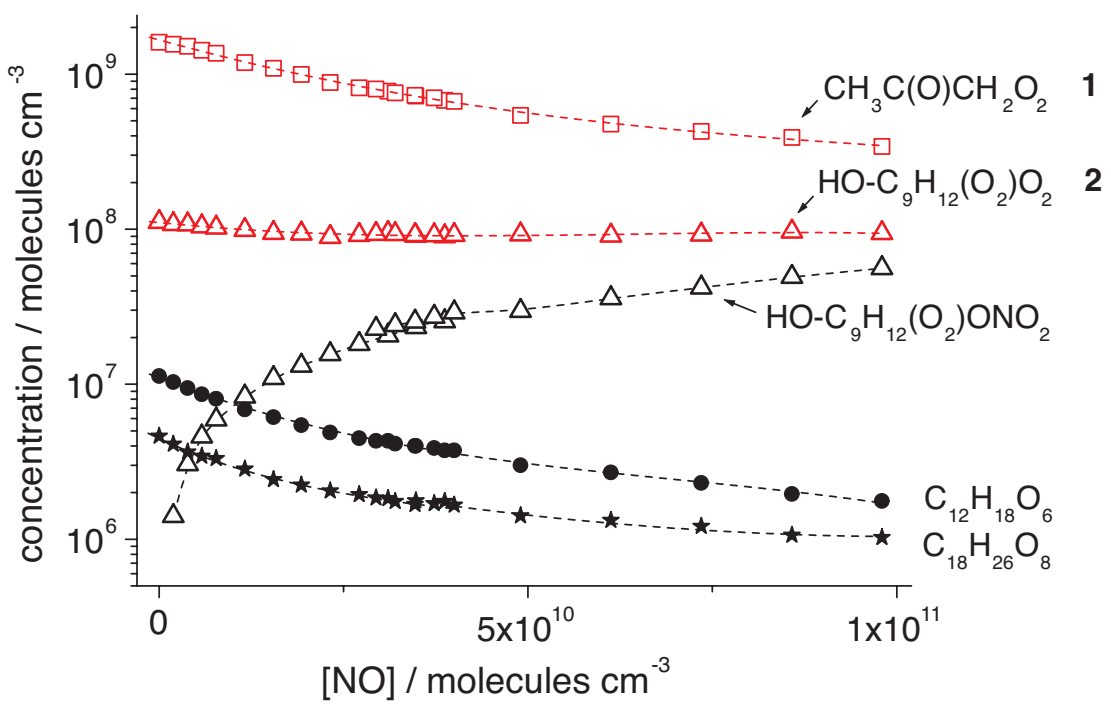

Figure 3. Main $\mathrm{RO}_{2}$ radicals 1 and $\mathbf{2}$ and closed-shell products of $\mathbf{2}$, i.e. the organic nitrate formed via $\mathrm{NO}+\mathrm{RO}_{2}$ $\rightarrow \mathrm{RONO}_{2}$ and the accretion products $\mathrm{C}_{12} \mathrm{H}_{18} \mathrm{O}_{6}$ and $\mathrm{C}_{18} \mathrm{H}_{26} \mathrm{O}_{8}$, as a function of the $\mathrm{NO}$ concentration. Colour coding of detection methods: red: $\mathrm{NH}_{4}{ }^{+}$-CI3-TOF; black: $\mathrm{C}_{3} \mathrm{H}_{7} \mathrm{NH}_{3}{ }^{+}$-APi-TOF. OH radical formation via TME ozonolysis. Reactant concentrations: $\left[\mathrm{O}_{3}\right]=1.24 \times 10^{12}$, $[\mathrm{TME}]=2.0 \times 10^{11}$ and $[1,3,5$-trimethylbenzene $]=4.06$ $\times 10^{12}$ molecules $\mathrm{cm}^{-3}$.

Recent results of chamber studies point to a possible importance of ozonolysis reactions and Criegee intermediates for accretion product formation based on the identification of selected aerosol constituents ${ }^{[17]}$ In order to examine the contribution of ozonolysis products on the observed ROOR' formation, experiments on the reaction of $\mathrm{OH}$ radicals with 1,3,5-trimethylbenzene were repeated in an ozonolysis-free system using isopropyl nitrite photolysis as $\mathrm{OH}$ radical source ${ }^{[18]}$. In the course of these experiments the $\mathrm{RO}_{2}$ radicals $\mathrm{HO}-\mathrm{C}_{9} \mathrm{H}_{12}\left(\mathrm{O}_{2}\right)_{\mathrm{x}} \mathrm{O}_{2}$ with $\mathrm{x}=1-3$ along with the corresponding accretion products were detected well in line with the findings from the TME ozonolysis experiments (Figure $\mathrm{S} 7$ and Figure S8). Kinetic analysis of the $\mathrm{C}_{18} \mathrm{H}_{26} \mathrm{O}_{8}$ formation from the self-reaction of 2 yields $\mathrm{k}_{4}=1.7 \times 10^{-10} \mathrm{~cm}^{3}$ molecule $\mathrm{s}^{-1}$ again in very good agreement with the outcome of the other experiments (Table 1 and Figure S9). These results emphasize the accretion product formation of ROOR' via pathway (1c) as a pure $\mathrm{RO}_{2}+\mathrm{R}^{\prime} \mathrm{O}_{2}$ gas-phase reaction without any hidden effects by ozonolysis products.

Significantly higher rate coefficients than $10^{-11} \mathrm{~cm}^{3}$ molecule $\mathrm{s}^{-1}$ of accretion product formation via pathway (1c) compensate partly the higher $\mathrm{NO}$ concentrations that drive the competitive $\mathrm{NO}+\mathrm{RO}_{2}$ 
reaction in the atmosphere. Even for NO concentrations of about $10^{11}$ molecules $\mathrm{cm}^{-3}$ (4 ppbv), as it is the case in polluted urban areas, the formation of accretion products via pathway (1c) is not fully

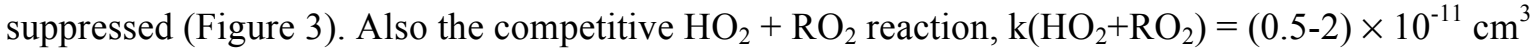
molecule ${ }^{-1} \mathrm{~s}^{-1[5]}$ and $\left[\mathrm{HO}_{2}\right]$ in the order of $10^{9}$ molecules $\mathrm{cm}^{-3}{ }^{[2]}$, cannot inhibit the rapid accretion product formation. Simple modelling calculations for realistic trace gas conditions in a polluted urban area confirm the importance of accretion product formation via pathway (1c), see Supplementary Information.

The general validity of product formation via pathway (1c) is demonstrated from a measurement series using 1-butene, isoprene, n-hexane or methane instead of 1,3,5-trimethylbenzene in the experiments with $\mathrm{OH}$ radical formation from TME ozonolysis. In each case, the corresponding accretion products from the self- and cross-reactions of $\mathrm{OH}$-reaction derived $\mathrm{RO}_{2}$ radicals, i.e. $\mathrm{HO}-\mathrm{C}_{4} \mathrm{H}_{8} \mathrm{O}_{2}, \mathrm{HO}-\mathrm{C}_{5} \mathrm{H}_{8} \mathrm{O}_{2}$, $\mathrm{C}_{6} \mathrm{H}_{13} \mathrm{O}_{2}$ or $\mathrm{CH}_{3} \mathrm{O}_{2}$, respectively, and $\mathbf{1}$ were identified, see Supplementary Information. Resulting rate coefficients are given in Table $\mathrm{S} 1$. It is to be noted that also small signals appeared for $\mathrm{CH}_{3} \mathrm{OOCH}_{3}$ from the $\mathrm{CH}_{3} \mathrm{O}_{2}$ radical self-reaction in line with earlier observations. ${ }^{[6 a]}$ Reliable data analysis in this case, however, was impossible.

Rate coefficients of accretion product formation from the self- and cross-reactions of $\mathrm{RO}_{2}$ radicals, as measured in this work, span a range of more than three orders of magnitude (Table 1 and Table S1).

The different $\mathrm{RO}_{2}$ reactivity in pathway (1c) is most likely connected to the $\mathrm{RO}_{2}$ functionalization. For instance, for the self-reaction of $\mathrm{C}_{6} \mathrm{H}_{13} \mathrm{O}_{2}, \mathbf{1}$ and 2 we obtained $9.2 \times 10^{-14}, 1.3 \times 10^{-12}$ and $1.4 \times 10^{-10}$ $\mathrm{cm}^{3}$ molecule ${ }^{-1} \mathrm{~s}^{-1}$, respectively. The highest k-value is observed for $2, \mathrm{HO}-\mathrm{C}_{9} \mathrm{H}_{12}\left(\mathrm{O}_{2}\right) \mathrm{O}_{2}$, bearing a hydroxyl and an endo-peroxide group beside the peroxy moiety ${ }^{[14]}$ and the lowest for $\mathrm{C}_{6} \mathrm{H}_{13} \mathrm{O}_{2}$ without an additional functional group. An analogous trend also exists for the series of reactions of 1 with other $\mathrm{RO}_{2}$ radicals. These observations point to attractive forces from donor-acceptor relationships between functional groups of the two reacting $\mathrm{RO}_{2}$ radicals as a necessary driving force for the rapid accretion product formation via pathway $(1 \mathrm{c}) \cdot{ }^{[19,20]}$ It can be speculated at this point that based on hydrogen bonds, carbonyl or endo-peroxide groups as acceptor and hydroxyl or carboxylic groups as donor, a more stable thus longer living reactive complex is generated that finally forms the covalently bound accretion product after $\mathrm{O}_{2}$ elimination.

Finally, the formed accretion products ROOR' can be treated as a source for secondary organic aerosol (SOA) due to their expected low vapour pressure in the case of functionalized ROOR'. Consequently, this process of accretion product formation can help to explain missing SOA sources in the atmosphere ${ }^{[21]}$, especially in urban areas characterized by high NO concentrations. ${ }^{[22]}$

\section{Acknowledgements}

We thank K. Pielok, A. Tilgner and A. Rohmer for technical assistance, the tofTools team for providing a data analysis toolbox, the Austrian Research Funding Association (FFG. Project Number 846050) for financial support and IONICON Analytik GmbH for in-kind contributions within the funded project 
[1] A. H. Goldstein, I. E. Galbally, Environ. Sci. Technol. 2007, 41, 1514-1521.

[2] B. Finlayson-Pitts, J. Pitts, Jr., Ed., Chemistry of the Upper and Lower Atmosphere (Academic Press, 1999).

[3] a) J. D. Crounse, L. B. Nielsen, S. Jorgensen, H. G. Kjaergaard, P. O. Wennberg, J. Phys. Chem. Lett. 2013, 4, 3513-3520; b) M. Ehn, et al., Nature 2014, 506, 476-479; c) T. Jokinen et al., Angew. Chem. Int. Ed. 2014, 53, 14596-14600; d) T. Berndt et al., Nat. Comm. 2016, 7, 13677.

[4] S. Richters, M. Pfeifle, M. Olzmann, T. Berndt, Chem. Commun. 2017, 53, 4132-4135.

[5] a) P. D. Lightfoot, R. A. Cox, J. N. Crowley, M. Destriau, G. D. Hayman, M. E. Jenkin, G. K. Moortgat, F. Zabel, Atmos. Environ. 1992, 26, 1805-1961; b) J. J. Orlando, G. S. Tyndall, Chem. Soc. Rev. 2012, 41, 6294-6317; c) T. J. Wallington, P. Dagaut, M. J. Kurylo, Chem. Rev. 1992, 92, 667710.

[6] a) J. Weaver, J. Meagher, R. Shortridge, J. Heicklen, J. Photochem. 1975, 4, 341-360; b) C. Anastasi, D. J. Waddington, A. Woolley, J. Chem. Soc., Faraday Trans. 1, 1983, 79, 505-516; c) C. A. McDowell, S. Sifniades, Can. J. Chem. 1963, 41, 300-307.

[7] MCM. Master Chemical Mechanism, MCMv3.3.1: http://mcm.leeds.ac.uk/MCM/ (2017). Last accessed 16. October 2017.

[8] a) T. F. Mentel, M. Springer, M. Ehn, E. Kleist, I. Pullinen, T. Kurtén, M. Rissanen, A. Wahner, J. Wildt, Atmos. Chem. Phys. 2015, 15, 6745-6765; b) T. Berndt, S. Richters, R. Kaethner, J.

Voigtländer, F. Stratmann, M. Sipilä, M. Kulmala, H. Herrmann, J. Phys. Chem. A 2015, 119, 1033610348.

[9] T. Jokinen et al., Proc. Natl. Acad. Sci. U.S.A. 2015, 112, 7123-7128.

[10] C. v.Sonntag, H.-P. Schuchmann, Angew. Chem. Int. Ed. Engl. 1991, 30, 1229-1253.

[11] A. Hansel, W. Scholz, B. Mentler, L. Fischer, T. Berndt, Atmos. Environ. 2017, submitted.

[12] D. Cabrera-Perez, D. Taraborrelli, R. Sander, A. Pozzer, Atmos. Chem. Phys. 2016, 16, 69316947.

[13] J. H. Kroll, S. R. Sahay, J. G. Anderson, K. L. Demerjian, N. M. Donahue, J. Phys. Chem. A 2001, 105, 4446-4457.

[14] a) D. R. Glowacki, L. Wang, M. J. Pilling, J. Phys. Chem. A 2009, 113, 5385-5396; b) S. Wang, R. Wu, T. Berndt, M. Ehn, L. Wang, Environ. Sci. Technol. 2017, 51, 8442-8449.

[15] a) R. A. Cox, J. Munk, O. J. Nielsen, P. Pagsberg, E. Ratajczak, Chem. Phys. Lett. 1990, 173, 206-210; b) I. Bridier, B. Veyret, R. Lesclaux, M. E. Jenkin, J. Chem. Soc. Faraday Trans. 1993, 89, 2993-2997.

[16] J. Arey, S. M. Aschmann, E. S. C. Kwok, R. Atkinson, J. Phys. Chem. A 2001, 105, 1020-1027. [17] a) K. Kristensen, T. Cui, H. Zhang, A. Gold, M. Glasius, J. D. Shuratt, Atmos. Chem. Phys. 2014, 14, 4201-4218, b) Y. Zhao, L. M. Wingen, V. Perraud, J. Greaves, B. J. Finlayson-Pitts, Phys. Chem. Chem. Phys. 2015, 17, 12500-12514; c) X. Zhang, R. C. McVay, D. D. Huang, N. F. Dalleska, B. Aumont, R. C. Flagan, J. H. Seinfeld, Proc. Natl. Acad. Sci. U.S.A. 2015, 112, 14168-14173.

[18] J. D. Raff, B. J. Finlayson-Pitts, Environ. Sci. Technol. 2010, 44, 8150-8155.

[19] L. Pauling, The nature of the chemical bond and the structure of molecules and crystals; an introduction to modern structural chemistry (3rd ed.) (Cornell University Press, 1960).

[20] A. I. Maergoiz, E. E. Nikitin, J. Troe, V. G. Ushakov, J. Chem. Phys. 1996, 105, 6277-6284.

[21] A M. Kulmala, et al., Science 2013, 339, 943-946.

[22] R. Volkamer, J. L. Jimenez, F. S. Martini, K. Dzepina, Q. Zhang, D. Salcedo, L. T. Molina, D. R. Worsnop, M. J. Molina, Geophys. Res. Lett. 2006, 33, L17811. 
Entry for the Table of Contents

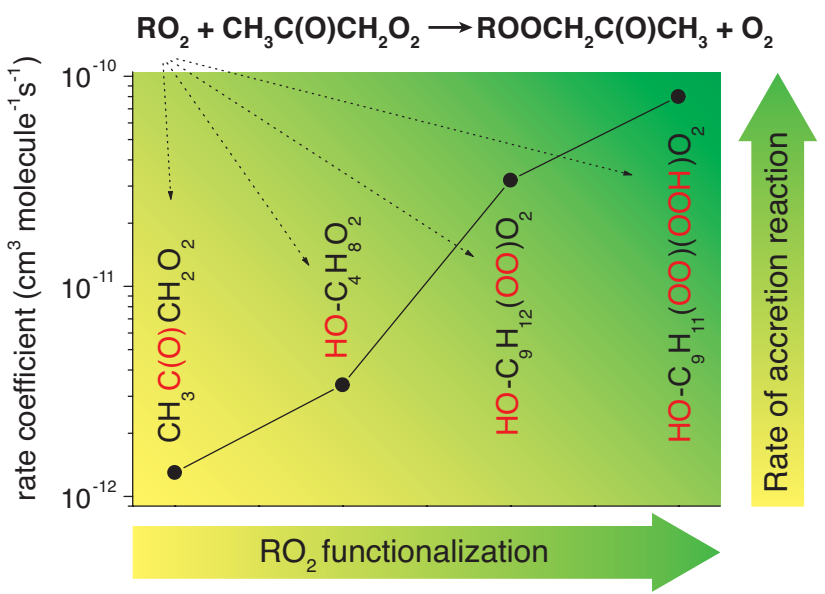

Rapid pairing up: $\mathrm{RO}_{2}$ radicals in the atmosphere form accretion products according to $\mathrm{RO}_{2}+\mathrm{R}^{\prime} \mathrm{O}_{2}$ $\rightarrow$ ROOR' $+\mathrm{O}_{2}$. This pathway is very efficient in the case of functionalized $\mathrm{RO}_{2}$ radicals reaching rates that surpass those of the competitive $\mathrm{NO}+\mathrm{RO}_{2}$ and $\mathrm{HO}_{2}+\mathrm{RO}_{2}$ reactions. Accretion product formation is currently not considered in the description of atmospheric oxidation processes.

Keywords:

Atmospheric chemistry

$\mathrm{RO}_{2}$ radical reactions

Accretion product

Mass spectrometry 